\title{
Professional Stress and Burnout Syndrome in Teachers: Are There Differences Among the Republic of Srpska Regions?
}

\author{
Nada Marić, ${ }^{1}$ Stefan Mandić-Rajčević, ${ }^{2}$ Nataša Maksimović, ${ }^{3}$ Petar Bulat ${ }^{4,5}$
}

\begin{abstract}
Introduction: Burnout syndrome occurs as a result of prolonged exposure to emotional and interpersonal stressors in the workplace and is characterised by three dimensions: emotional exhaustion, depersonalization and personal achievements. Research and prevention of this phenomenon are of public health importance due to numerous consequences it leaves on the health of the working population and work organisation, and among teachers, on children as direct users of their services. The research aims to examine the presence of the stress and burnout syndrome at work in teachers in the regions of the Republic of Srpska, as well as to determine the existence of differences between regions.

Methods: The research was conducted as a cross-sectional study in the period August-September 2018, in the territory of the Republic of Srpska. The target population was represented by teachers of primary and secondary schools. The response rate in all regions was $75 \%$ or above it. For this research, a special questionnaire was constructed, consisting of sociodemographic data, data on economic characteristics of the respondents, characteristics of the work environment, as well as data on satisfaction with equipment and resources at work, support from family and friends and presence of work-life conflict. In addition to the general questionnaire, the Maslach Burnout Inventory-Human Services Study (MBI-HSS) questionnaire for the assessment of the burnout syndrome at work, and Karasek's questionnaire (Job Content Questionnaire) for the assessment of stress at work were used.

Results: A statistically significant difference in the prevalence of occupational stress among teachers between RS regions was found. Also, a statistically significant difference was found between the regions of the Republic of Srpska related to the dimensions of burnout syndrome at work. A high level of emotional exhaustion was more often reported by teachers from the territory of the region of East Sarajevo and Prijedor ( $8.0 \%$ and $7.7 \%$ ) comparing to teachers from other regions. Teachers from the territory of Prijedor more often showed moderate and high levels of depersonalization, as well as a low level of personal achievements comparing to teachers from other regions.

Conclusion: This research shows the presence of burnout syndrome in teachers of all the Republic of Srpska regions at the beginning of the school year, as well as statistically significant differences between the regions. This indicates the need for additional research on risk factors by regions to form targeted and thus more effective prevention measures.
\end{abstract}

Key words: Burnout syndrome; Occupational stress; Professional stress; Teachers; Educators; Workplace.
(1) Institute of Occupational Health and Sports Medicine of the Republic of Srpska - Centre Bijeljina, Bijeljina, the Republic of Srpska, Bosnia and Herzegovina.

(2) School of Public Health and Health Management and Institute of Social Medicine, Faculty of Medicine, University of Belgrade, Belgrade, Serbia.

(3) Institute of Epidemiology, Faculty of Medicine, University of Belgrade, Belgrade, Serbia

4) Serbian Institute of Occupational Health, Belgrade, Serbia.

(5) Faculty of Medicine, University of Belgrade, Belgrade, Serbia.

Correspondence:

NADA MARIĆ

E: drnadamaric@gmail.com

M: +38765840103

\section{ARTICLE INFO}

Received: 31 October 2020 Revision received: 5 November 2020 Accepted: 22 November 2020 


\section{Introduction}

Burnout syndrome has intrigued the scientific public since the 1970s. ${ }^{1,2}$ According to Christina Maslach, it is traditionally defined as a three-dimensional concept and is characterised through emotional exhaustion, depersonalisation and personal achievements. ${ }^{1}$ Since 2019 , it has been included in the international classification of diseases and is defined as a mental state characterised by lack of energy or exhaustion, increased mental distance from work or a feeling of negativity or cynicism related to work, as well as a reduction of professional success. $^{3}$

Burnout syndrome occurs as a response to prolonged exposure to emotional and interpersonal stressors in the workplace and is mostly related to helping/support professions whereas employees are exposed to constant emotional demands (health workers, social workers, psychologists, and teachers). ${ }^{1}$

Research and prevention of this phenomenon are of public health significance due to numerous consequences it has on the mental and physical health of the working population (insomnia, depression, psychosomatic diseases, cardiovascular disease, musculoskeletal disorders, etc.), but also on work organisations (job dissatisfaction, absenteeism, presentism, disability pensions). ${ }^{4}$ At the same time, various authors point out that it is inevitable that burnout syndrome at work also represents a significant economic burden for the state. ${ }^{5,6} \mathrm{How}$ ever, more recent specific data on economic consequences have not been found in the literature. The significance of this phenomenon could bear an even higher burden in the population of teachers. Researchers have shown that it is associated with long-term consequences on the academic achievements of students and a negative impact on their emotional development and mental health. ${ }^{7,8}$

An analysis shows that the prevalence of burnout syndrome in the teacher population has a wide range (eg, emotional exhaustion 20-40\%, depersonalization 9-20\%). ${ }^{9,}{ }^{10}$ Data show that the system of values and beliefs, influencing behaviour and attitudes, have a significant impact on the variance of the burnout syndrome. ${ }^{11}$ Thus, the authors on the study conducted in Germany and Syria noticed the existence of the difference between countries and the question of the possible influence of culture is raised. ${ }^{12}$ Bearing in mind that the Republic of Srpska, as part of Bosnia and Herzegovina $(\mathrm{BiH})$, is multinational and multi-ethnic, the goal of this research was to determine the frequency of occupational stress and burnout syndrome at work in the Republic of Srpska regions, as well as the possible existence of differences among the Republic of Srpska regions.

\section{Methods}

The research was conducted as a cross-sectional study before the start of the 2018/2019 school year in the period August-September on the territory of the Republic of Srpska regions at the Institute of Occupational Health and Sports Medicine of the Republic of Srpska in Banja Luka and regional centres (Prijedor, Doboj, Bijeljina, East Sarajevo and Trebinje). It was approved by the Ethics Committee of the Institute of Occupational Medicine and Sports of the Republic of Srpska.

According to the Law on Primary Education and Upbringing of the Republic of Srpska and the Law on Secondary Education and Upbringing of the Republic of Srpska, before the beginning of the school year all school workers are obliged to undergo a medical examination. The research was conducted during the medical examination, and the target population consisted of primary and secondary school teachers. Participation was offered to one out of four teacher who applied for the examination randomly and was conducted anonymously and voluntarily.

The response rate in all regions was $75 \%$ or above it (Banja Luka $84 \%$, Prijedor $75 \%$, Doboj $78 \%$, Bijeljina $91 \%$, East Sarajevo 79 \%, Trebinje $81 \%$ ).

A special questionnaire was constructed for this research. It consisted of a general questionnaire that included standard sociodemographic data (gender, age, marital status, parenthood), data on the economic characteristic of the respondents (material condition of the household assessed by five-points Likert scale). Also, variables on the characteristics of the work environment (length of the service, overtime work) and variables on personal satisfaction with equipment and resources for work, family and friends support (estimated 
by five-points Likert scale) were included and the presence of work-life conflict was determined. For the determination of work-life conflict, the standard question which is already used in the literature was used "In the last three weeks, how often were you annoyed or upset because of the inability to reconcile work with family and/or partner commitments?".13

In addition to the general questionnaire, linguistically adapted and validated questionnaires have been used, Maslach Burnout Inventory-Human Services Study (MBI-HSS) for the assessment of the burnout syndrome at work and Karasek's (Job Content Questionnaire) for the assessment of the stress at work. MBI-HSS has a total of 22 items and consists of three scales: the emotional exhaustion scale ( 9 items), the depersonalisation/cynicism scale (5 items) and the personal achievement scale (8 items). Each scale consists of a series of statements that express the range of agreement with the statements and the categories of answers are given through a six-point Likert scale. The overall attitude of every examinee was obtained by summing, specific key, the matrix for each of the three previously mentioned scales. High exhaustion and cynicism frequency contribute to burnout syndrome, while the high frequency of personal achievements reduces it. ${ }^{14}$ Karasek's questionnaire is frequently used in the world for assessing the stress level in the work environment and has shown satisfactory psychometric characteristics. ${ }^{15}$ The Serbian version has 22 questions and measures two basic constructs: psychological demands of the workplace (job demand) (5 questions) and autonomy in the workplace ie, freedom of decision-making (job control) (9 questions). The job control scale has two subscales: skill-discretion (6 items) and decision latitude (3 items). The questionnaire also measures two additional constructs that are considered to be moderators of the demand-control relationship, which are: co-worker support (4 items) and superiors support ( 4 items). Also, the job strain calculated by a specific formula as the ratio job demands-job control, where a score above 1 indicates the existence of the workload. ${ }^{16}$

Methods of descriptive and inferential statistics were used in the work. From the methods of descriptive statistics, measures of central tendency (arithmetic mean and median), variability measures (standard deviation), and relative numbers depending on the type of data were used.
Chi-square test was used to compare the frequency between the groups, and the Fisher test when the expected frequency was less than 5 . The normality of the distribution was assessed using the Kolmogorov-Smirnov test, and the Shapiro-Wilk test. Depending on the type of data, adequate Student $t$ test or Mann-Whitney tests were used to assess the difference in the distribution of independent variables between different categories of source variables and ANOVA or Kruskal Wallis test were used for variables with more modalities (eg, differences between the regions). In the case of more than two groups, pairwise comparison adjusting for multiple testing was also performed (Tukey in case the row-variable was normally distributed or Benjamini-Hochberg method if this condition was not met). IBM SPSS Statistics 25 software was used for statistical data analysis. The results are shown in tables and graphs for statistical significance of $p<0.05$ and high statistical significance $\mathrm{p}<0.01$.

\section{Results}

Sociodemographic characteristics of respondents The gender distribution of teachers of the Republic of Srpska regions was similar. Almost half of the teachers $(48.6 \%)$ from the Prijedor region were 46 and older, while in other regions the number of teachers aged over 46 ranged from $26.2 \%$ to $36.6 \%$ and this difference between the regions was statistically significant $(\mathrm{p}=0.007)$. Besides, the largest percentage of teachers in the Prijedor region showed divorced status or their spouses had died $(13.6 \%)$. In other regions, the same data gave $2.5-9.7 \%$ and this difference between the regions was statistically significant $(p=0.009)$. Sociodemographic characteristics of teachers in the regions of the Republic of Srpska are presented in Table 1.

Life and work characteristics of the respondents A statistically significant difference between regions was found in all examined life and work characteristics of teachers $(p<0.01)$. All of the teachers who participated in the research in the Doboj region worked in primary schools. In other regions, the number of teachers working in primary schools ranged from $44.8 \%$ in Bijeljina to $72.9 \%$ in Banja Luka. A small proportion of teachers (5 
Table 1: Sociodemographic characteristics of the participating teachers in various regions in the Republic of Srpska

\begin{tabular}{|c|c|c|c|c|c|c|c|}
\hline $\begin{array}{l}\text { Sociodemographic } \\
\text { characteristics }\end{array}$ & $\begin{array}{l}\text { Banja Luka } \\
\text { N (\%) }\end{array}$ & $\begin{array}{c}\text { Prijedor } \\
\text { N (\%) }\end{array}$ & $\begin{array}{l}\text { Doboj } \\
\text { N (\%) }\end{array}$ & $\begin{array}{c}\text { Bijeljina } \\
\text { N (\%) }\end{array}$ & $\begin{array}{c}\text { East Sarajevo } \\
\text { N (\%) }\end{array}$ & $\begin{array}{c}\text { Trebinje } \\
\text { N (\%) }\end{array}$ & p \\
\hline \multicolumn{8}{|l|}{ Gender } \\
\hline - Male & $76(26.1)$ & $55(25.1)$ & $16(20.0)$ & $27(28.1)$ & $30(26.5)$ & $46(30.3)$ & 0.669 \\
\hline - Female & $215(73.9)$ & $164(74.9)$ & $64(80.0)$ & $69(71.9)$ & $83(73.5)$ & $106(69.7)$ & \\
\hline \multicolumn{8}{|l|}{ Age (years) } \\
\hline - 25-35 & $98(33.7)$ & $49(22.3)$ & $30(37.5)$ & $35(36.5)$ & $34(30.1)$ & $40(26.3)$ & $0.007^{*}$ \\
\hline - $36-45$ & $101(34.7)$ & $64(29.1)$ & $29(36.2)$ & $35(36.5)$ & $42(37.2)$ & $56(36.8)$ & \\
\hline$\cdot 46-55$ & $53(18.2)$ & $63(28.6)$ & $12(15.0)$ & $15(15.5)$ & $16(14.2)$ & $27(17.8)$ & \\
\hline - 56 and high & $39(13.4)$ & $44(20.0)$ & $9(11.2)$ & $11(11.5)$ & $21(18.6)$ & $29(19.1)$ & \\
\hline \multicolumn{8}{|l|}{ Marital status } \\
\hline - Single & $58(19.9)$ & $35(15.9)$ & $18(22.5)$ & $25(26.0)$ & $29(25.7)$ & $42(27.6)$ & $0.009^{*}$ \\
\hline - Married & $215(73.9)$ & $155(70.5)$ & $60(75.0)$ & $65(67.7)$ & $73(64.6)$ & $99(65.1)$ & \\
\hline - Divorced/Widower & $18(6.2)$ & $30(13.6)$ & $2(2.5)$ & $6(6.2)$ & $11(9.7)$ & $22(7.2)$ & \\
\hline \multicolumn{8}{|l|}{ Children } \\
\hline - Yes & $205(70.4)$ & $166(75.5)$ & $56(70.0)$ & $62(64.6)$ & $75(66.4)$ & $94(61.8)$ & 0.091 \\
\hline - No & $86(29.6)$ & $54(24.5)$ & $24(30.0)$ & $34(35.4)$ & 38 (33.6) & $58(38.2)$ & \\
\hline
\end{tabular}

Chi-squared test and Fisher exact test were used for statistical analysis of the data. Bolded numbers denote values significantly different from the ones for other regions

Table 2: Work-life characteristics of the participating teachers in various regions in the Republic of Srpska

\begin{tabular}{|c|c|c|c|c|c|c|c|}
\hline $\begin{array}{l}\text { Work-life } \\
\text { characteristics }\end{array}$ & $\begin{array}{l}\text { Banja Luka } \\
\text { N (\%) }\end{array}$ & $\begin{array}{l}\text { Prijedor } \\
\text { N (\%) }\end{array}$ & $\begin{array}{l}\text { Doboj } \\
\text { N (\%) }\end{array}$ & $\begin{array}{c}\text { Bijeljina } \\
\text { N (\%) }\end{array}$ & $\begin{array}{c}\text { East Sarajevo } \\
\text { N (\%) }\end{array}$ & $\begin{array}{l}\text { Trebinje } \\
\text { N (\%) }\end{array}$ & p \\
\hline \multicolumn{8}{|l|}{ Type of school } \\
\hline - Primary & $212(72.9)$ & $128(58.2)$ & $80(100.0)$ & $43(44.8)$ & $63(55.8)$ & $89(58.6)$ & $0.000^{*}$ \\
\hline - Secondary & $76(26.1)$ & $91(41.4)$ & 0 & $51(53.1)$ & $50(44.2)$ & $62(40.8)$ & \\
\hline \multicolumn{8}{|l|}{ Length of work (years) .. } \\
\hline$\bullet \leq 10$ & $119(40.9)$ & $74(33.6)$ & $38(47.5)$ & $47(49.0)$ & $46(40.7)$ & $52(34.2)$ & $0.000^{*}$ \\
\hline - $11-20$ & $106(36.4)$ & $51(23.2)$ & $26(32.5)$ & $34(35.4)$ & $36(31.9)$ & $52(34.2)$ & \\
\hline - $>20$ & $66(22.7)$ & 95 (43.2) & $16(20.0)$ & $15(15.6)$ & $31(27.4)$ & $48(31.6)$ & \\
\hline \multicolumn{8}{|c|}{ Overtime work (per week) } \\
\hline - Never & $234(80.4)$ & $165(75.0)$ & $72(90.0)$ & $60(62.5)$ & $85(75.2)$ & $106(69.7)$ & $0.000^{*}$ \\
\hline - Up to $10 \mathrm{~h}$ & $56(19.2)$ & $53(24.1)$ & $8(10.0)$ & $32(33.3)$ & $28(24.8)$ & $44(28.9)$ & \\
\hline$\bullet>10 \mathrm{~h}$ & $1(0.4)$ & $2(0.9)$ & 0 & $4 \quad(4.2)$ & 0 & 2 (1.4) & \\
\hline \multicolumn{8}{|l|}{ Work-life conflict } \\
\hline - Yes & $140(48.1)$ & $184(83.6)$ & $27(33.8)$ & $57(59.4)$ & $56(49.6)$ & $77(50.7)$ & $0.000^{*}$ \\
\hline - No & $151(51.9)$ & $36(16.4)$ & $53(66.2)$ & $39(40.6)$ & $57(50.4)$ & 75 (49.3) & \\
\hline \multicolumn{8}{|c|}{ Satisfaction with equipment } \\
\hline - Very unsatisfied & $18(6.2)$ & $8 \quad(3.6)$ & $2(2.5)$ & $2(2.1)$ & $1(1.8)$ & $1(0.7)$ & $0.000^{*}$ \\
\hline - Unsatisfied & $99(64.0)$ & $46(20.9)$ & $6(7.5)$ & $25(26.0)$ & $35(31.0)$ & $44(28.9)$ & \\
\hline - Neutral & $59(20.3)$ & $57(25.9)$ & $19(23.8)$ & $19(19.8)$ & $24(21.2)$ & $34(22.4)$ & \\
\hline - Satisfied & $108(37.1)$ & $105(47.7)$ & $47(58.8)$ & $49(51.0)$ & $51(45.1)$ & $65(42.8)$ & \\
\hline - Very satisfied & $7 \quad(2.4)$ & $4(1.8)$ & $6(7.5)$ & $1(1.0)$ & $1(0.9)$ & $8(5.3)$ & \\
\hline \multicolumn{8}{|c|}{ Satisfaction with monthly income } \\
\hline - Very unsatisfied & $12(4.1)$ & $41(18.6)$ & 1 (1.2) & $2(2.1)$ & $9(8.0)$ & $11 \quad(7.2)$ & $0.000^{*}$ \\
\hline - Unsatisfied & $101(34.7)$ & $107(48.6)$ & $11(13.8)$ & $23(24.0)$ & $47(41.6)$ & $46(30.3)$ & \\
\hline - Neutral & $64(22.0)$ & $45(20.5)$ & $14(17.5)$ & $19(19.8)$ & $17(15.0)$ & $32(21.1)$ & \\
\hline - Satisfied & $112(38.5)$ & $26(11.8)$ & $50(62.5)$ & $51(53.1)$ & $39(34.5)$ & $61(40.1)$ & \\
\hline - Very satisfied & $2(0.7))$ & $1(0.5)$ & $4 \quad(5.0)$ & $1(1.0)$ & $1(0.9)$ & $2(1.3)$ & \\
\hline \multicolumn{8}{|c|}{$\begin{array}{l}\text { Satisfaction with Supports of } \\
\text { friends/ family }\end{array}$} \\
\hline - Very unsatisfied & $8(2.7)$ & $6 \quad(2.7)$ & $3(3.8)$ & $2(2.1)$ & $2(1.8)$ & $3(2.0)$ & $0.000^{*}$ \\
\hline - Unsatisfied & $7(2.4)$ & $15 \quad(6.8)$ & 0 & 0 & 0 & $2(1.3)$ & \\
\hline - Neutral & $21(7.3)$ & $33(15.0)$ & $3(3.8)$ & $5(5.2)$ & $7(6.2)$ & $16(10.5)$ & \\
\hline - Satisfied & $142(48.8)$ & $119(54.1)$ & $32(40.0)$ & $46(47.9)$ & $59(52.2)$ & 78 (51.3) & \\
\hline - Very satisfied & $113(38.8)$ & 47 (1.4) & $42(52.4)$ & $43(44.8)$ & 45 (39.8) & $53(34.9)$ & \\
\hline
\end{tabular}


Table 3: Karasek's model of stress at work of the participating teachers in various regions in the Republic of Srpska

\begin{tabular}{|c|c|c|c|c|c|c|c|}
\hline $\begin{array}{l}\text { Karasek's model } \\
\text { of stress }\end{array}$ & $\begin{array}{c}\text { Banja Luka } \\
\text { X (SD) }\end{array}$ & $\begin{array}{l}\text { Prijedor } \\
\text { X (SD) }\end{array}$ & $\begin{array}{l}\text { Doboj } \\
\text { X (SD) }\end{array}$ & $\begin{array}{l}\text { Bijeljina } \\
\text { X (SD) }\end{array}$ & $\begin{array}{c}\text { East Sarajevo } \\
\text { X (SD) }\end{array}$ & $\begin{array}{l}\text { Trebinje } \\
\text { X (SD) }\end{array}$ & $\mathbf{p}$ \\
\hline Job demand & 28.31 & 29.31 & 26.78 & 27.55 & 28.70 & 28.08 & $0.001^{*}$ \\
\hline \multirow[t]{2}{*}{ Skill-discretion } & 37.13 & 35.70 & 39.62 & 38.19 & 38.92 & 37.74 & $0.000^{*}$ \\
\hline & $(5.09)$ & $(5.33)$ & $(4.14)$ & (3.92) & $(4.74)$ & $(4.17)$ & \\
\hline Decision latitude & $(4.08)$ & $(4.85)$ & $(3.43)$ & (3.90) & $(4.21)$ & (4.38) & \\
\hline \multirow[t]{2}{*}{ Supervisor support } & 11.91 & 10.94 & 12.21 & 12.07 & 12.62 & 11.81 & $0.000^{*}$ \\
\hline & $(2.14)$ & $(2.56)$ & $(2.58)$ & $(2.21)$ & $(2.18)$ & $(2.40)$ & \\
\hline \multirow[t]{2}{*}{ Co-workers support } & 11.79 & 11.00 & 12.20 & 11.57 & 11.71 & 11.36 & $0.000^{*}$ \\
\hline & (1.69) & (1.79) & (1.66) & $(1.60)$ & (1.99) & (1.94) & \\
\hline
\end{tabular}

teachers) worked in both an elementary as well as a high school and they were excluded from analyses that consider the workplace. In the territory of the Prijedor region, teachers more often had a longer work experience, ie, work experience $>20$ years ( $43 \%$ ), while in other regions the frequency of teachers with the same work experience was 15-31\%. Overtime work was mostly reported by teachers from the Bijeljina region, $37 \%$ (up to 10 family/friends (56.5\%), while in other regions the same parameter ranged $86 \%-92 \%$. Work-life characteristics are presented in Table 2.

\section{Professional stress}

A statistically significant difference among the Republic of Srpska regions in the frequency of job strain among teachers was noticed $(p<0.05)$ and results are presented in Figure 1.

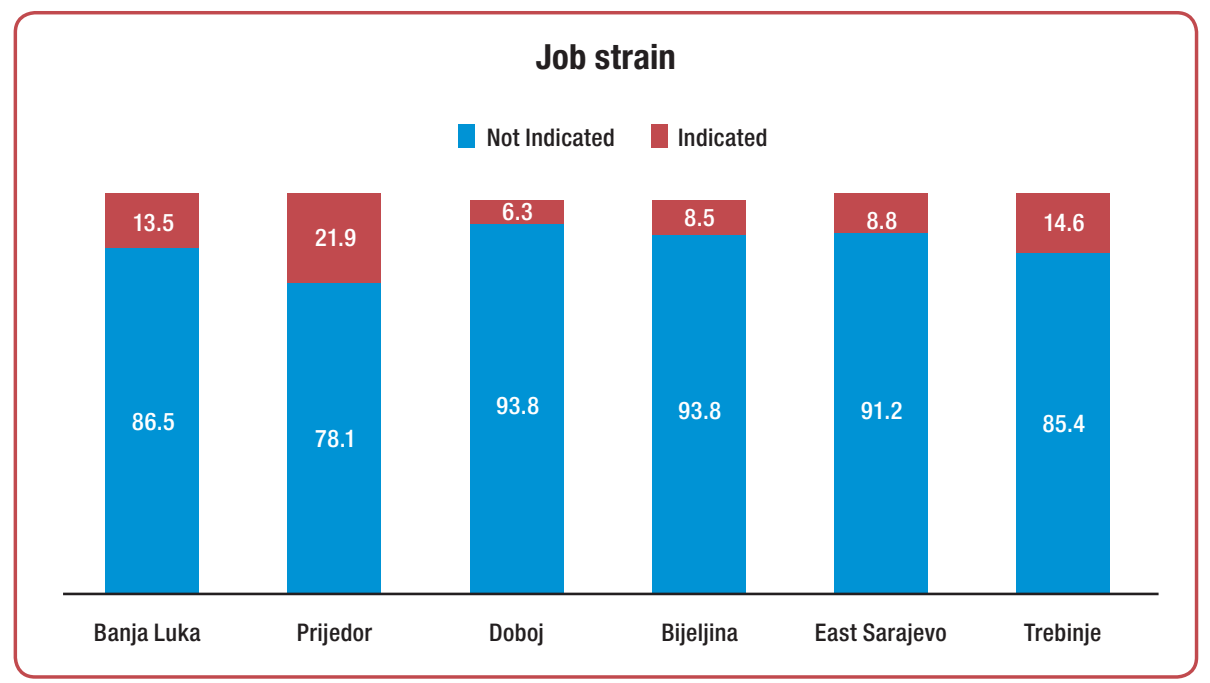

Figure 1: Job strain of the participating teachers in various regions in the Republic of Srpska

h $33 \%$ and $>10$ h $4 \%$ ), while in other regions the frequency ranged from $10 \%$ in the Doboj region (only up to 10 hours) to $29 \%$ in the region of Trebinje (up to $10 \mathrm{~h} 28 \%$ and $>10 \mathrm{~h} 1 \%$ ). The conflict between the roles of work and family life were mostly reported by teachers belonging to the Prijedor region (83.6\%), and least often in Doboj $(33.8 \%)$. Dissatisfaction with the equipment at work was mostly expressed by teachers from the territory of the Banja Luka region (70 $\%)$ and least often in Doboj (10 \%). With the personal monthly income, teachers from the territory of Prijedor showed great dissatisfaction (67\%), while in Doboj was the least (15\%). In the Prijedor region, teachers reported that they were the least satisfied with the support they had from
Results of Karasek's model of stress at work by regions of the Republic of Srpska are presented in Table 3. A statistically significant difference was found between regions on all scales of Karasek's model of stress at work $(\mathrm{p}<0.05)$.

\section{Burnout syndrome at work}

A statistically significant difference among the regions of the Republic of Srpska in the dimensions of the burnout syndrome was found $(\mathrm{p}<0.01)$. Compared to other regions, a high level of emotional exhaustion was more frequently reported by teachers from the territory of the East Sarajevo and the Prijedor region ( $8.0 \%$ and $7.7 \%$ ). Emotional exhaustion of teachers in the Republic of Srpska regions is presented in Figure 2. 

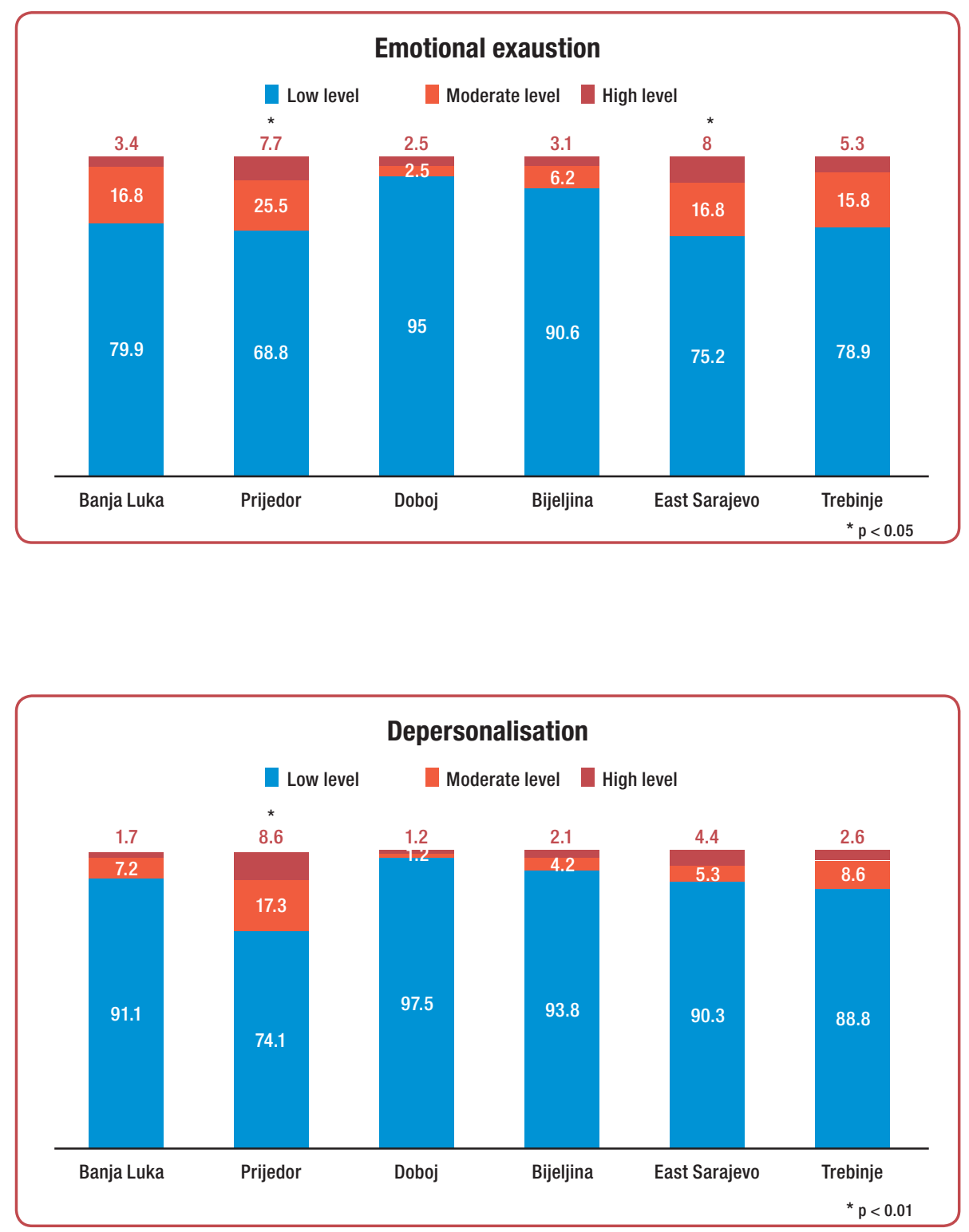

Personal achievements

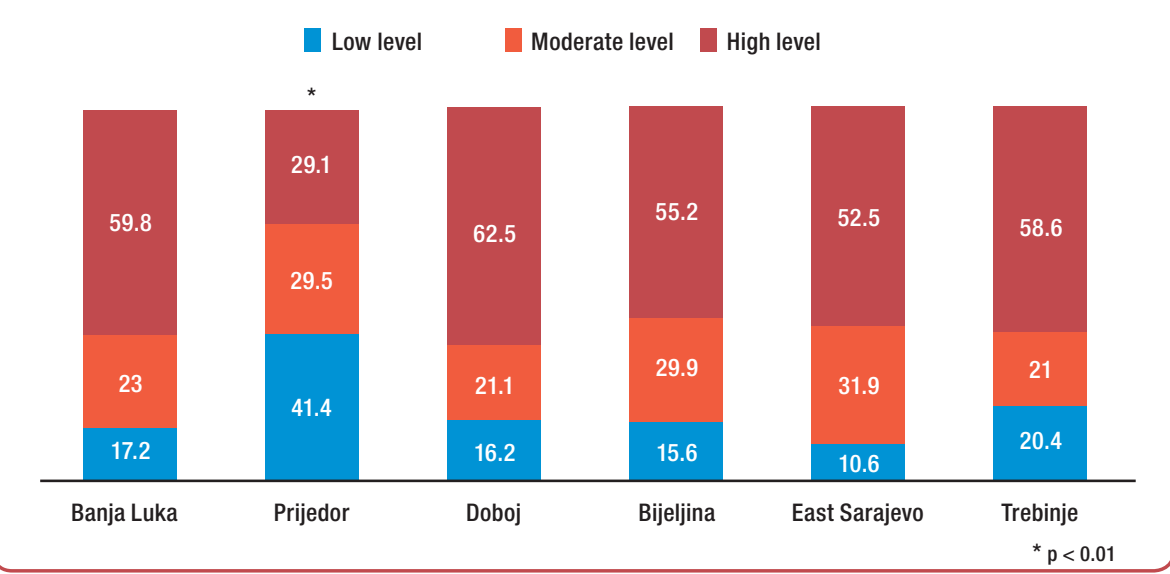

Figure 2: Levels of emotional exhaustion of the participating teachers in various regions in the Republic of Srpska
Figure 3: Levels of depersonalisation of the participating teachers in various regions in the Republic of Srpska
Figure 4: Levels of personal achievements of the participating teachers in various regions in the Republic of Srpska 
Table 4: Burnout syndrome at work of the participating teachers in various regions in the Republic of Srpska

\begin{tabular}{|c|c|c|c|c|c|c|c|c|c|}
\hline \multirow[b]{2}{*}{ Regions } & \multicolumn{3}{|c|}{ Emotional exhaustion } & \multicolumn{3}{|c|}{ Depersonalisation } & \multicolumn{3}{|c|}{ Personal achievements } \\
\hline & $\begin{array}{c}X \\
\text { (SD) }\end{array}$ & $\begin{array}{c}\text { Med } \\
(\text { Min-Max) }\end{array}$ & p & $\begin{array}{c}X \\
\text { (SD) }\end{array}$ & $\begin{array}{c}\text { Med } \\
\text { (Min-Max) }\end{array}$ & $\mathbf{p}$ & $\begin{array}{c}X \\
\text { (SD) }\end{array}$ & $\begin{array}{c}\text { Med } \\
\text { (Min-Max) }\end{array}$ & $\mathbf{p}$ \\
\hline Banja Luka & (8.27) & $(0.00-39.00)$ & & $(3.11)$ & $(0.00-21.00)$ & & $(8.27)$ & $(0.00-48.00)$ & \\
\hline Prijedor & 13.07 & 11.00 & & 4.46 & 3.00 & & 32.35 & 32.00 & \\
\hline \multirow[t]{2}{*}{ Doboj } & 5.90 & 5.00 & & 0.96 & 4.52 & & 38.99 & 41.00 & \\
\hline & $(6.40)$ & $(0.00-35.00)$ & & $(2.12)$ & $(0.00-15.00)$ & & $(8.71)$ & $(12.00-48.00)$ & \\
\hline \multirow[t]{2}{*}{ Bijeljina } & 7.98 & 6.00 & & 1.64 & 0.50 & & 38.68 & 39.50 & \\
\hline & (6.93) & $(0.00-34.00)$ & & $(2.72)$ & $(0.00-14.00)$ & & (7.11) & $(12.00-48.00)$ & \\
\hline East Sarajevo & 11.55 & 9.00 & & 2.35 & 1.00 & & 38.53 & 39.00 & \\
\hline
\end{tabular}

A statistically significant difference was also found in the prevalence of depersonalisation among the Republic of Srpska regions ( $<<0.01$ ). Depersonalisation of teachers by the Republic of Srpska regions are presented in Figure 3.

A statistically significant difference was found in the scale of personal achievements among teachers from different regions $(p<0.01)$. Personal achievements of teachers by regions of the Republic of Srpska are presented in Figure 4.

A statistically significant difference was also found concerning the scores of the dimensions of the burnout syndrome. The scores of the dimensions of the burnout syndrome at work are presented in Table 4.

\section{Discussion}

This is the first study exploring the difference in burnout syndrome at work and occupational stress between teachers in different regions of the Republic of Srpska.

The gender distribution of teachers in the regions was similar. In all regions, the larger fraction consisted of female teachers (Table 1). These results correspond to the data of the Republic of Srpska Institute of Statistics, according to which mostly female teachers work in the Republic of Srpska. ${ }^{17,18}$ In research on the teacher population, other authors also noticed this population is mostly made up of female teachers ${ }^{19-21}$ and pointed out the reason for this is that teaching is considered to be a female profession. ${ }^{22,23}$

A statistically significant difference in the age of the teachers among regions has been found. Almost half of the teachers in the region of Prijedor were 46 and older (Table 1). The results of age distribution by regions are similar (except for the Prijedor region) to the data of the Republic of
Srpska Institute of Statistics, according to which the majority of teachers are under the age of 44 . It is not known why older teachers participated in the research more often in the Prijedor region. A statistically significant difference in the marital status of teachers was found among regions. In the Prijedor region, teachers were more commonly divorced or widowed compared to other regions (Table 1). Also, in the Prijedor region, teachers reported they were least satisfied with the support they have from family/friends. A conflict between the roles of work and family life was most often reported by teachers belonging to the Prijedor region (Table 2), which could explain the significantly more frequent status of divorced people in this region compared to others. These results indicate the need for further research on the quality of life, especially in the Prijedor region, and possible factors that affect the quality of life of this region population.

The analysis by the regions showed a statistically significant difference in the school type among 
regions. In the Doboj region, all teachers worked in primary education, while in the region of Bijeljina half of teachers worked in secondary education (Table 2). It is not known why in the Doboj region in the research participated only teachers working in primary schools.

Statistically significant differences between the Republic of Srpska regions were also determined by other examined work and life characteristics (Table 2). Teachers from the region of Prijedor were most dissatisfied with their monthly income (67.2\%), and the least in Doboj (15\%). These results also raise questions for further research on teacher dissatisfaction and factors influencing differences in satisfaction among the regions.

A statistically significant difference regarding the presence of professional stress was found among teachers from different regions. Teachers from the Prijedor region most often reported the presence of job strain (21.9\%), while in other regions the frequency ranged from $6.3 \%$ in Doboj to $14.6 \%$ in Trebinje (Figure 1). By analysing Karasek's model of stress at work, the results showed that teachers from the Prijedor region have the highest score on the scale of demands at work, and the least on the scales of freedom to choose skills and support in the workplace (Table 3 ). Having in mind the above results, it is necessary to conduct additional researches within the working environment of teachers on the territory of the Prijedor region.

The results of the research show the differences in the frequency of burnout syndrome at work between the regions of the Republic of Srpska. High level of emotional exhaustion was mainly reported by teachers belonging to the region of East Sarajevo and Prijedor (Figure 2). In the research conducted in the Republic of Srpska, concerning the factors that influence the development of burnout syndrome at work among teachers, ${ }^{24}$ conflicts of roles and satisfaction with the support of family and friends proved to be one of the important factors. Bearing in mind teachers from the Prijedor region had conflict roles much more often and were more dissatisfied with the support, that can explain the reason for the much more frequent emotional exhaustion in this region. Also, teachers from this region who participated in the research were mostly teachers older than 45 years (Table 1) and had more years of work experience (Table 2) which can also be an explanation for the more frequent manifestation of emotional exhaustion. Other authors ${ }^{21,24,25}$ also pointed out that older teachers more often report emotional exhaustion, explaining that with age, it is more and more difficult to face student's problems on daily basis. Teachers from the territory of the Prijedor region more often showed a moderate and high level of depersonalization (Figure 3), so as a low level of personal achievement (Figure 4) comparing to teachers who belong to other regions. Having in mind the results of Karasek's model of stress at work for the Prijedor region, where the teachers had a high score of demands at work and low scores on the subscale of autonomy in the workplace, the frequent occurrence of burnout syndrome at work is expected. According to Karasek's model of stress at work, the most vulnerable occupations for the development of burnout syndrome at work are the one where the workers are exposed to high demands on the workplace, and a little possibility of control. As moderators of this demand-control connection are the support employees have from their colleagues and superiors. ${ }^{15,26}$ Earlier, the authors emphasized that various aspects of the work environment at school affect the perception of the stress at work and the development of the burnout syndrome at work, such as administrative (hierarchy, management), and physical (cleanliness, space).$^{27}$ Given the above results on the difference between regions, additional research within the regions on living and working characteristics is inevitably needed, as well as the inclusion of other factors (eg, individual).

However, in addition to the region of Prijedor, teachers from the territory of East Sarajevo often had higher levels of emotional exhaustion compared to teachers from other regions, and their sociodemographic and life-work characteristics were similar to those of teachers from other regions, which opens the need for further research in this region to find reasons for these results. It is possible that, in the development of the burnout syndrome in teachers in this region, a significant role is played by individual characteristics, for which previous research has also shown to have a significant contribution. ${ }^{28}$

This is the first research regarding the differences between regions in the Republic of Srpska in the burnout syndrome in teachers. One of the advantages is the use of linguistically adapted, validated, and standardised questionnaires. The disadvantage of the research is primarily the design of the study, which makes it impossible to determine the causal relationship. Another disadvantage is that some factors (role conflict, 
self-assessment of satisfaction) were measured based on only one question. One part of the teachers did not fill in the questionnaires, which could have had an impact on the results. In the region of Doboj, the teachers from secondary schools did not participate.

\section{Conclusion}

This research has pointed out the presence of burnout syndrome at work in all the Republic of Srpska regions at the beginning of the school year, to the existence of differences between them. An earlier proposal to introduce a screening programme as part of mandatory medical examinations is significant in all regions. Also, due to presented differences, this research indicates the need for additional research of risk factors by regions to form targeted and thus more effective prevention measures.

\section{References}

1. Maslach C, Schaufeli WB, Leiter MP. Job burnout. Annu Rev Psychol 2001;(52):397-422.

2. Schaufeli WB, Leiter MP, Maslach C. Burnout : 35 years of research and practice. Career Dev Int 2008;14(3):20420.

3. WHO Mental Health. Burn-out an "occupational phenomenon": International Classification of Diseases. 2019. Available at: www.who.int/mental_health/evidence/burn-out/en.

4. Salvagioni DAJ, Melanda FN, Mesas AE, González AD, Gabani FL, de Andrade SM. Physical, psychological and occupational consequences of job burnout: a systematic review of prospective studies. PLOS ONE 2017 Oct 4;12(10):e0185781. doi: 10.1371/journal. pone.0185781.

5. Shirom A. Reflections on the study of burnout. Work Stress 2005;19(3):263-70.

6. Lastovkova A, Carder M, Rasmussen HM, Sjoberg L, de Groene GJ, Sauni R, et al. Burnout syndrome as an occupational disease in the European Union: an exploratory study. Ind Health 2017;56:160-5.

7. Herman KC, Hickmon-Rosa J, Reinke WM. Empirically derived profiles of teacher stress, burnout, self-efficacy, and coping and associated student outcomes. J Posit Behav Interv 2018;20(2):90-100.

8. Harding S, Ford T, Evans R., Brockman R, Araya R, et al. Is teachers' mental health and wellbeing associated with students' mental health and wellbeing? J Affect Disord 2019;242:180-7.

9. García-Carmona M, Marín MD, Aguayo R. Burnout syndrome in secondary school teachers: a systematic review

\section{Acknowledgements}

The study was funded by the Ministry of Education, Science and Technological Development of the Republic of Serbia (project No. 200110). The funders had no role in study design, data collection and analysis, decision to publish, or preparation of the manuscript.

\section{Conflict of interest}

None. and meta-analysis. Social Psychol Educ 2019:22(1):189208.

10. García-Arroyo JA, Segovia AO, Peiró JM. A meta-analytical review of teacher burnout across 36 societies: the role of national learning assessments and gender egalitarianism. Psychol Health 2019;34(6):733-53.

11. Taras V, Steel P, Kirkman BL. Does Country Equate with Culture? Beyond geography in the search for cultural boundaries. Manag Internat Review 2016;56(4):455-72.

12. Schwarzer R, Hallum S. Perceived teacher self-efficacy as a predictor of job stress and burnout: Mediation analyses. Appl Psychol 2008;57:152-71.

13. Roberts DL, Shanafelt TD, Dyrbye LN, West CP. A national comparison of burnout and work-life balance among internal medicine hospitalists and outpatient general internists. J Hosp Med 2014;9(3):176-81.

14. Matejić B, Milenović M, Kisić Tepčević D, Simić D, Pekmezović T, Worley AJ. Psychometric properties of the Serbian version of the Maslach burnout inventory-human services survey: a validation study among anesthesiologists from Belgrade teaching hospitals. ScientificWorldJournal 2015:903597. doi: 10.1155/2015/903597.

15. Sale JEM, Kerr MS. The psychometric properties of Karasek's demand and control scales within a single sector: data from a large teaching hospital. Int Arch Occup Environ Health 2002;75(3):145-52.

16. Work and Health CHS M278 / EHS M270. Questionnaire Packet Instructions and Scoring. 2012. Available at: https://unhealthywork.org/wp-content/ uploads/2012_Practice_Questionnaire_Directions_and_ Scoring.pdf. 
17. Institute of the statistics Republic of Srpska. Primary education. Statistical bulletin. Banja Luka. 2018. Available at: https://www.rzs.rs.ba/front/category/262/.

18. Institute of the statistics Republic of Srpska. Secondary education. Statistical bulletin. Banja Luka. 2018. Available at: https://www.rzs.rs.ba/front/article/3017/.

19. Arvidsson I, Håkansson C, Karlson B, Björk J, Persson R. Burnout among Swedish school teachers: a cross-sectional analysis. BMC Public Health 2016;16(1):823. doi: 10.1186/s12889-016-3498-7.

20. Schwarzer R, Schmitz GS, Tang C. Teacher burnout in Hong Kong and Germany: a cross-cultural validation of the Maslach burnout inventory. Anxiety Stress Coping 2000;13(3):309-26.

21. Wang Y, Ramos A, Wu H, Liu L, Yang X, Wang J, et al. Relationship between occupational stress and burnout among Chinese teachers: a cross-sectional survey in Liaoning, China. Int Arch Occup Environ Health 2015;88(5):589-97.

22. Brütting J, Druschke D, Spitzer S, Seibt R. Health status of long-term sick leave and working female teachers in Germany: A cross-sectional study. Int Arch Occup Environ Health 2017;31(2):227-42.
23. Ervasti J, Kivimäki M, Pentti J, Suominen S, Vahtera J, Virtanen M. Sickness absence among Finnish special and general education teachers. Occup Med 2011;61(7):46571.

24. Marić N, Mandić-Rajčević S, Maksimović N, Bulat P. Factors associated with burnout syndrome in primary and secondary school teachers in the Republic of Srpska (Bosnia and Herzegovina). Internat J Environ Res Public Health 2020;17(10):3595. doi: 10.3390/ ijerph17103595.

25. Kamtsios S. Burnout syndrome and stressors in different stages of teachers professional development. Hell J Psychol 2018;15:229-53.

26. Karasek RA. Job demands, job decision latitude, and mental strain: implications for job redesign. Adm Sci Q 1979;24(2):285-308.

27. Friedman I. High and low burnout schools culture aspects of teacher burnout. J Educ Res 1991;84(6):325-33.

28. Alarcon G, Eschleman KJ, Bowling NA. Relationships between personality variables and burnout: a meta-analysis. Work Stress 2009;23(3):244-63. 